\title{
Overview of Boost Converters for Photovoltaic Systems
}

\author{
Saleh E. Babaa, Georges El Murr, Faisal Mohamed, Srilatha Pamuri \\ System Engineering Department, Military Technological College (Affiliated with University of Portsmouth, UK), \\ Muscat, Oman \\ Email: elkelani12@yahoo.com
}

How to cite this paper: Babaa, S.E., El Murr, G., Mohamed, F. and Pamuri, S. (2018) Overview of Boost Converters for Photovoltaic Systems. Journal of Power and Energy Engineering, 6, 16-31. https://doi.org/10.4236/jpee.2018.64002

Received: March 16, 2018

Accepted: April 27, 2018

Published: April 30, 2018

Copyright (c) 2018 by authors and Scientific Research Publishing Inc. This work is licensed under the Creative Commons Attribution International License (CC BY 4.0).

http://creativecommons.org/licenses/by/4.0/

\section{cc) (i) Open Access}

\begin{abstract}
DC-DC boost power converters play an important role in solar power systems; they step up the input voltage of a solar array for a given set of conditions. This paper presents an overview of the variance boost converter topologies. Each boost converter is evaluated on its capability to operate efficient, size, and cost of implementation. Conventional boost converter and interleaved boost converter are widely used topologies in photovoltaic systems reported; however, they have negative sides of varied efficiency level under changed weather conditions. Therefore, this paper proposes, interleaved boost converter with novel switch adaptive control, to maximise efficiency of standalone photovoltaic system under change of solar power levels, due to illadation condition.
\end{abstract}

\section{Keywords}

DC-DC Boost Converters, Efficiency, Maximum Power Point Tracking (MPPT), Photovoltaic (PV) System

\section{Introduction}

Over the last twenty years, the issue of energy supply has been widely discussed due to the shortage in oil and gas, increasing fuel prices, and rapid increase in energy demand due to continued growth in global population and industrialisation [1]. Solar power technology is a renewable source of energy and has several advantages such as; no fuel cost, a little maintenance requirement, and friendly on the environment [2]. Standalone photovoltaic systems are very popular in water pumping and lighting solutions in developed countries, isolated villages, and small urban and rural communities. The PV systems also became a choice method of profits for generating electricity, especially in developed regions that 
have a substantial amount of solar irradiation [3].

For photovoltaic applications, boost converter performs better than buck and buck-boost converters [2]. And the requirements of PV systems should operate with high efficiency level, small size, with low cost. Therefore, this paper studies boost converters for stand-alone photovoltaic systems, with the goal of bringing best performance over a wide range of operation conditions.

The amount of power generated from solar panel, significantly depends on temperature and irradiation where irradiation levels have a dramatic effect on the maximum power of the solar panel [4]. With varied weather conditions, the PV system should continuously operate, with great efficiency level near/at the maximum power point (MPP) of the solar panel. Several Maximum Power Point Tracking (MPPT) methods have been studied, and improved with consideration to their techniques of optimization [5] [6] [7]. Though, the maximum power point tracking cannot solve power converter efficiency when it falls in various terms of power generations. Thus, with an objective to have maximum power to varied load, the efficiency level of power converter must also be upgraded.

The paper provides an overview of the most common dc-dc boost converters. From this, it is found that the conventional boost converter and the interleaved boost converter have advantages and disadvantages in a long term of operation under varied PV power due to change of weather condition. Therefore, anointer leaved boost converter with novel switch adaptive control are proposed to combine advantages of conventional boost converter and interleaved boost converter, to operate efficiently under varied solar power levels. Mainly, the topology design with its controller is affordable and simple. For this reason, this paper presents a simulation study comparing the relative efficiency performance of the low-cost selected converters with respect to the standalone PV system under a wide range of irradiation conditions.

\section{Boost Converters}

The survey is to study technical viability of dc-dc boost converter which is able to generate a low dc voltage level to a high dc voltage level that required by a load. The used converter is usually evaluated according to economic point, power distortion through the PV system, and the efficiency conversion under wide range of PV power as follow review.

\subsection{Conventional Boost Converter}

The conventional boost converter which could be used in many power electronic applications, for example in regulated DC power supplies, and in photovoltaic systems. The value to stepping up a low DC input voltage to higher DC output voltage of desired load. The converter has two mode of current operations, discontinuous current mode (DCM) and continuous current mode (CCM). In power applications, the conventional boost converter is able to operate in any 
mode of current operation under changed power levels, and with each mode has variance characteristics.

The principle operation of the DC-DC conventional boost converter shown in Figure 1. When the switch is on, the diode becomes reverse biased, thus, isolating the load stage. The input source stores energy in the inductor. Once the power switch is off, the load stage gets energy from the inductor as well as from the source, therefore the load voltage is greater than the source voltage. Conventional boost converter has a simple circuit and low cost [8]. The disadvantages of conventional boost converter are high ripple current on active and passive components, large voltage stress for power switches, and require a large capacitor value to keep the output voltage steady [9]. This difficulty can be solved by using interleaved boost converter which is another power boost converter circuit [10].

\subsection{Interleaved Boost Converter}

The circuit design of interleaved boost converter as shown in Figure 2, is used to improve the power processing capability and to operate the solar systems with its maximum power [11].

Interleaved step-up converter topology works with binary branches operating 180 degree out of phase from each other. Generally, each phase operates in the same fashion as the conventional boost converter previously described. When switch two turns on, the current ramps up in inductor two, with a slope depending on the source voltage that stores energy in inductor two, the diode two is off during this time since the output voltage is higher than the input voltage. When switch two turns off, diode two connect and deliver energy to the output

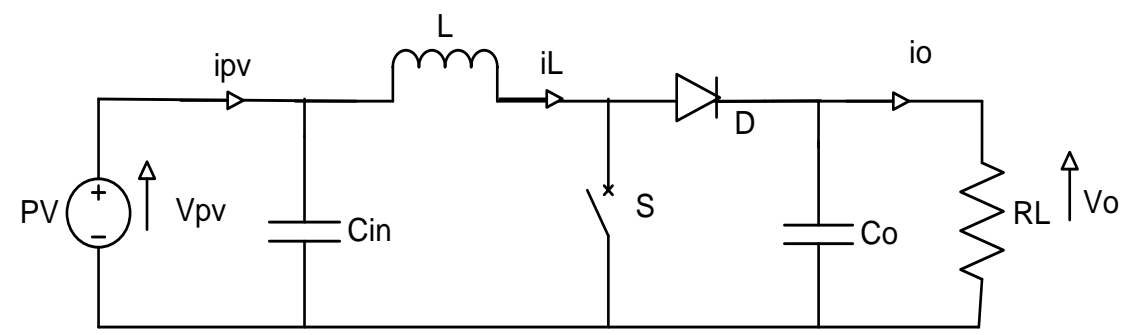

Figure 1. Conventional boost converter.

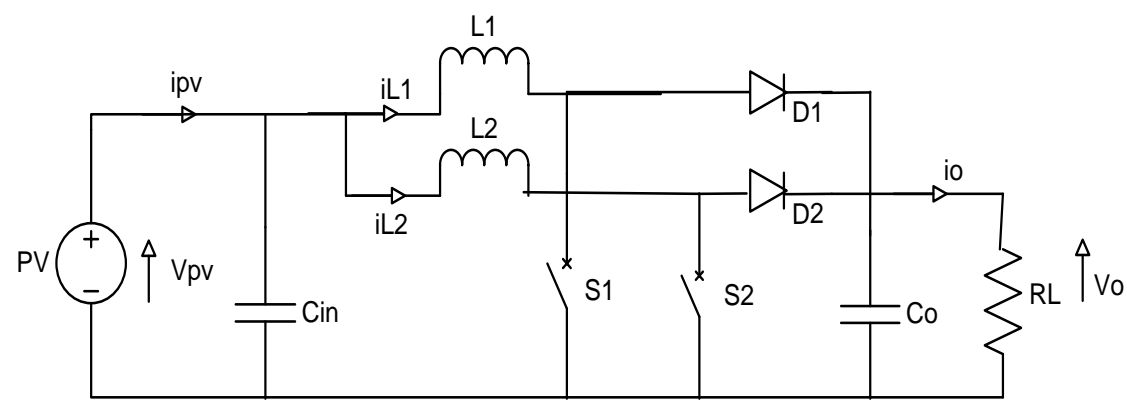

Figure 2. Interleaved boost converter. 
capacitor and the load, and current of inductor two ramps down with a slope dependent on the difference between the source and load voltage. One half of a switching period later, switch one also will turn on to complete the same cycle of events.

The advantage of the interleaved boost converter gives low ripple power at the output and input stages due to an effective increase in switching frequency, hence the interleaved has chance to minimize output and input capacitor filters which will be relatively large if conventional boost converter is used [11]. Additionally, greater efficiency level achieved by forcing the input current to move and shared in the two limbs, substantially decreasing $\left(I^{2} R\right)$ power losses. Moreover, the converter gives low stresses on the passive and active components due to current split which rise power process capability [12] [13] [14] [15]. On the other side, using the interleaved boost converter, rises the number of to pologyelements which may lead to more cost. Though, the use of additional components in interleaved converter can be with lower rated power due to the shared current in its two limbs, and in photovoltaic power systems, long term improve the power generation proficiencies and could help to offset this disadvantage.

\subsection{New Interleaved Isolated Boost Converter}

This converter is presented by Jun Wen [16], it is developed from the basic structure of isolated boost converter, and it is main feature is suitable to power applications that require to step-up high voltage. It is modified by two cells helping each other in secondary side and in primary side, which is simpler than parallel connection to the output side of two basic dual isolated boost converters. In practical to convert DC voltage from a lower level to a higher level, require isolated boost converter to give high current at the source and high voltage at the load. If two cells are connected in parallel in isolated boost converter at the input stage and in series at the output stage, this structure will reduce the current stress and voltage stress on active devices and the transformer rate of the converter could be reduced to the half [16].

New interleaved isolated boost converter publicized in Figure 3, with double inductors connected in parallel at the input stage to share the input current equally, and at the output two capacitors in series sharing the voltage equally. thus, the new interleaved isolated boost converter offers less stress of voltage and current at power switches and transformer [17]. Altogether these advantages make the new interleaved isolated boost converter suitable for low to high converter applications [16].

\subsection{Interleaved Boost Converter Based on the L-Type Half Bridge}

The converter is shown in Figure 4, discussed by J. Wen, Taotao Jin, and Keyue Smedley [16]. The Interleaved boost converter based on the L-type half bridge converter is one of the ideal option to use for high power applications because it has several advantages such as low current stress on transformer and inductors 


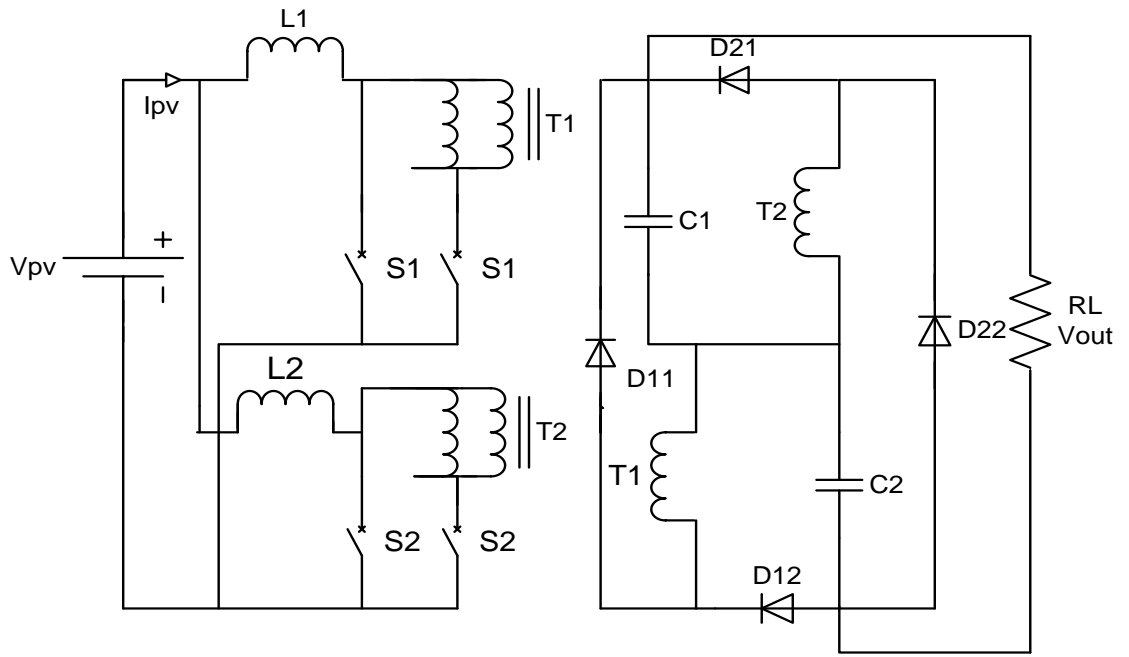

Figure 3. New interleaved isolated boost converter.

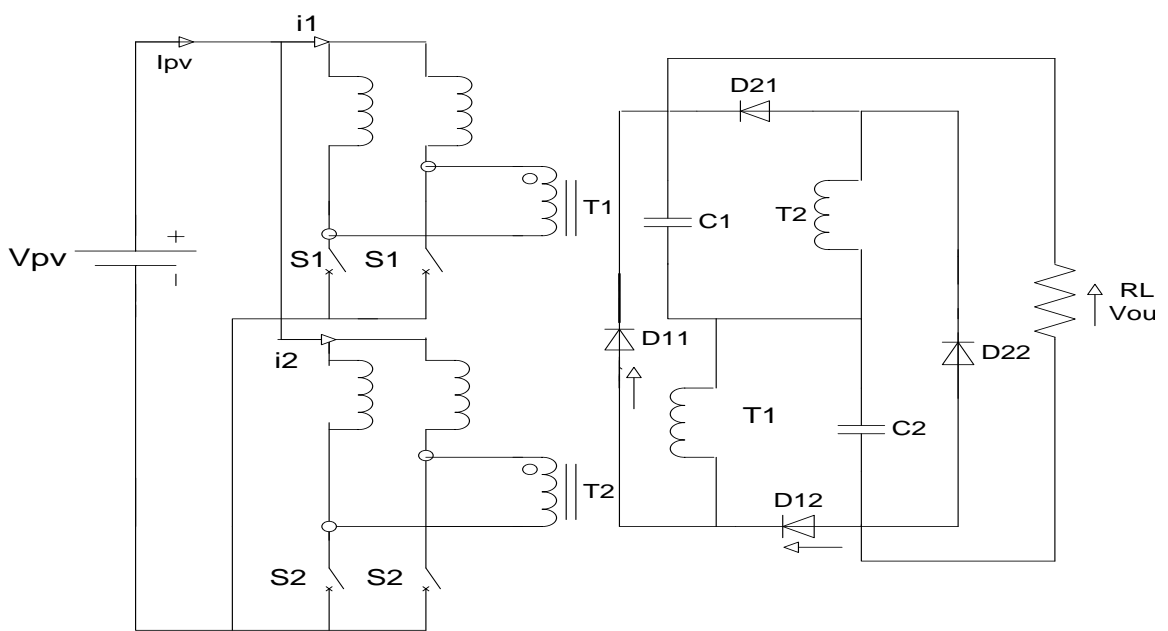

Figure 4. Interleaved boost converter based on the L-type half bridge.

hence small size can be designed, and switches are simple to drive since they are grounded. Moreover, circuit configuration is symmetrical so soft switching is easy to be implemented [16] [17]. On other side, the converter has more inductors than other boost converters.

\subsection{Push Pull Converter}

The topology of push-pull converter is introduced by Yao Wang [18] to face the requirements of PV systems, as shown in Figure 5 and Figure 6, the first circuit is fed by voltage mode and the second by current mode. The advantages and disadvantages are summarised below for both circuits, the advantage in both modes of push-pull converter, it is clear has fewer elements in current path which reduces conduction losses [19]. In the input inductor, in current mode operation the switches in duty ratio more than 50 percent ( $D>50 \%$ ), this will reduce the frequency current ripple drawn from solar arrays. The auxiliary 


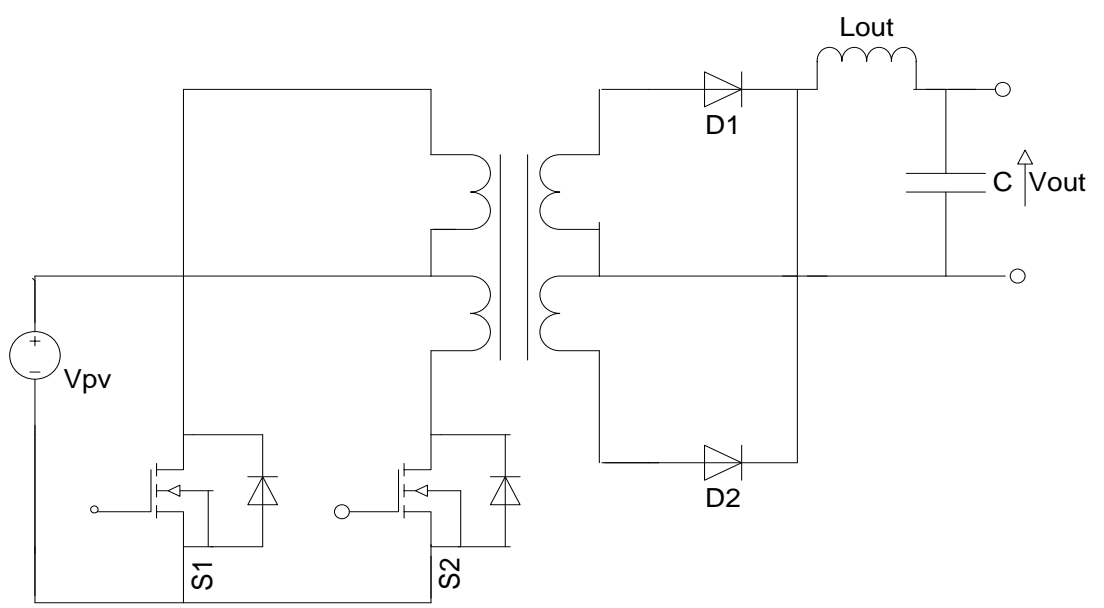

Figure 5. Voltage-fed push pull converter.

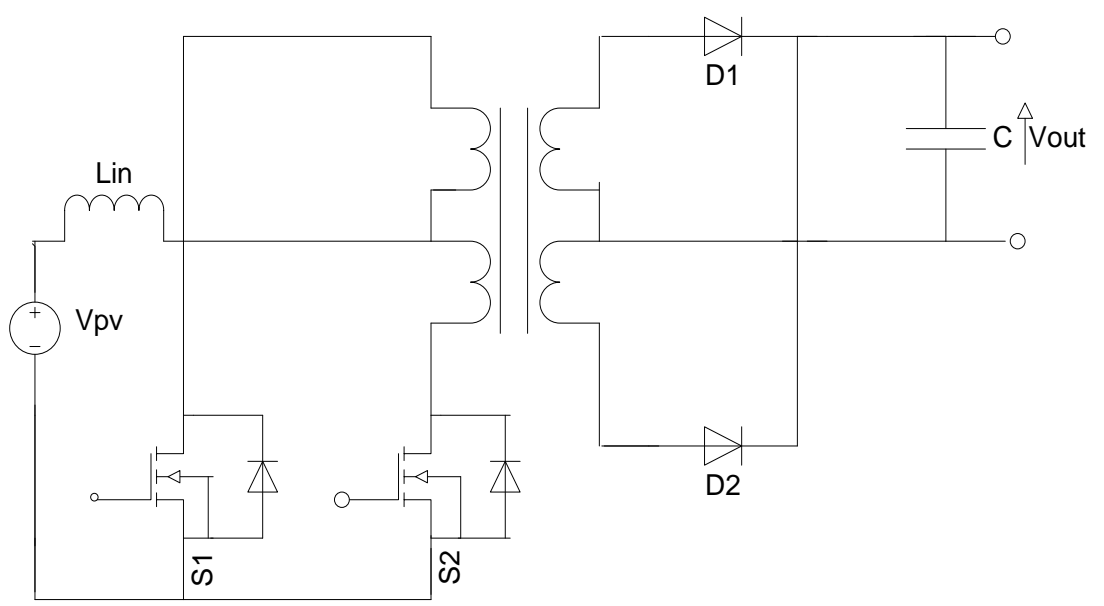

Figure 6. Current-fed push pull converter.

circuit is preferred for push pull converter to reduce the voltage stress on the power switches [20], and the energy stored in a leakage inductance of the transformer can be safely removed. The disadvantage of push pull converter is challenging a problem that the switches have to withstand double the input voltage peak, this causes increase in conduction power losses [18].

\subsection{Full and Half Bridge Converter}

The half-bridge and full-bridge topologies shown in Figure 7 and Figure 8, which are presented by Y. Wang and Christian Klumpner [18], use untapped primary transformer windings. It is known that such transformers, feature better utilization of the copper, also these topologies feature reduced device voltage stress that is equal to the input voltage.

The half-bridge topology has a riven capacitor bus, a two transformer turn ratio and devices current in compare with full bridge leading to increased transformer loss and size. 


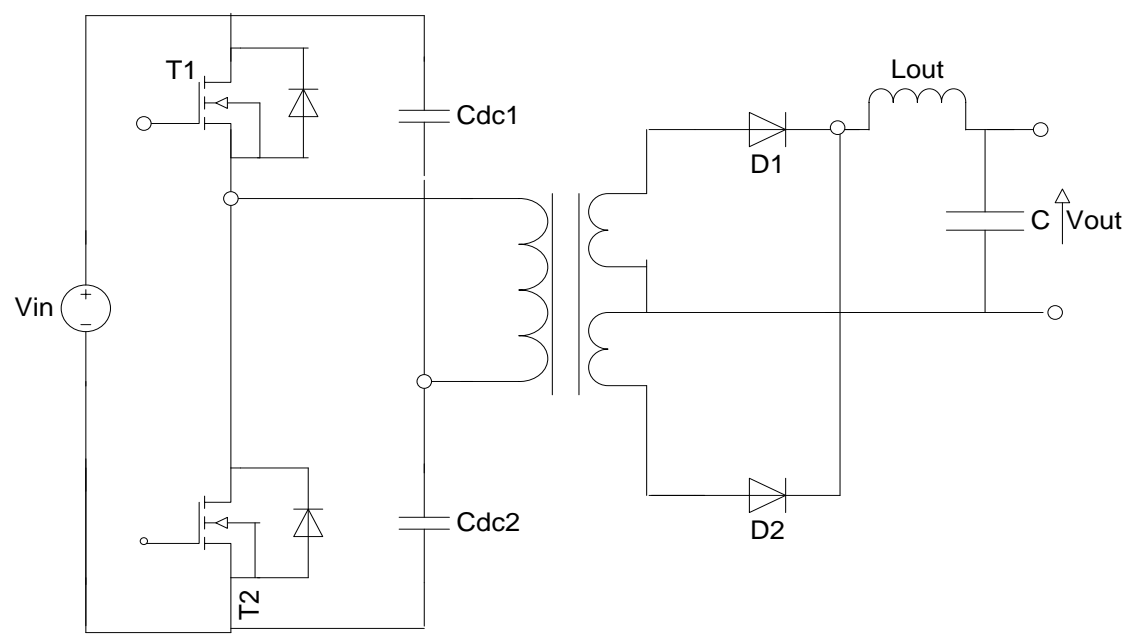

Figure 7. Half-bridge DC/DC converter.

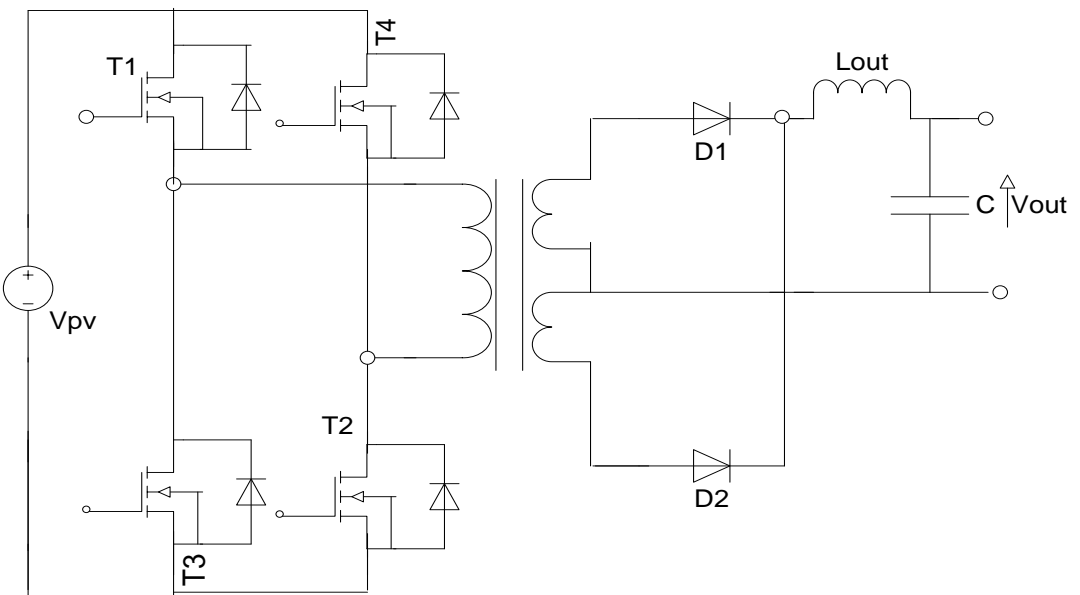

Figure 8. Full-bridge DC/DC converter.

The Full bridge is well suited for application which requires a wide input voltage range [21], and for high power applications [21], also can be operated in zero voltage switching modes (ZVS) that leads to reduction in switches loss with high frequency value. Furthermore, zero voltage switching can be crucial to reduce size and cost. Also, the operation of high frequency gives small size and cost for magnetic components [18]. Although the full-bridge topology requires more switches, it reduces voltage and current stress [18]. Full wave rectifier topology with a centred tapped secondary winding and two diodes are used to maximize the efficiency [22], smaller size and lower cost devices, and to make sure lowest voltage drop across the diodes. Though, the voltage blocking ability of the diodes is double higher than for a diode bridge rectifier.

\subsection{Novel High Efficiency Step up Converter}

Novel high step up converter has been proposed by K. Tseng and T. Liang [23] [24] to give high efficiency with less voltage stress on power switches, diodes, and capacitors. The scheme of this converter comprises of voltage boost cell and 
an energy clamp circuit. The utility of the converter is an active clamp circuit to limit the voltage spike on power switch during turn off transient period [23] [24]. In order to increase the output voltage, the fly back converter output terminal and boost converter output terminal are serially connected with coupled inductor as shown in Figure 9.

Advantages of the offered converter, it has simple control technique of current mode PWM for duty cycle lower 50 percent and the leakage energy is recycled to the output. Moreover, voltage stress is reduced on switching element, and high efficiency are achieved by the low Rds (on) voltage. in addition, lower rating of the power switching device is achieved, also this converter is able to achieve high step up ratio [23]. Although, ripple of current is still high comparing to conventional interleaved boost converter.

\section{Discussion}

Several DC-DC boost converters have been reviewed in this paper, and these types of boost converters have the capabilities to step up the voltage from a low level to a high level in photovoltaic systems. The choice of top suitable boost converter to be used in a PV system, is difficult to be ascertained due to the fact that each boost converter has advantages and disadvantages and the choice is highly application dependent.

For example, it is obvious that to design some boost converters needs more components that will increase the cost. However, almost all DC-DC boost converters offer a low stress current and a low stress voltage on the power semiconductor switches of each topology. In addition, the difference in requirements of photovoltaic applications be contingent on (location-voltage-type of system), and also, it is important to consider both the consumer requirements and manufacturer specifications. In general, after evaluation to some various step-up converters, conventional boost converter and interleaved boost converter are ideal for the use in standalone PV systems because they are relatively easy to be

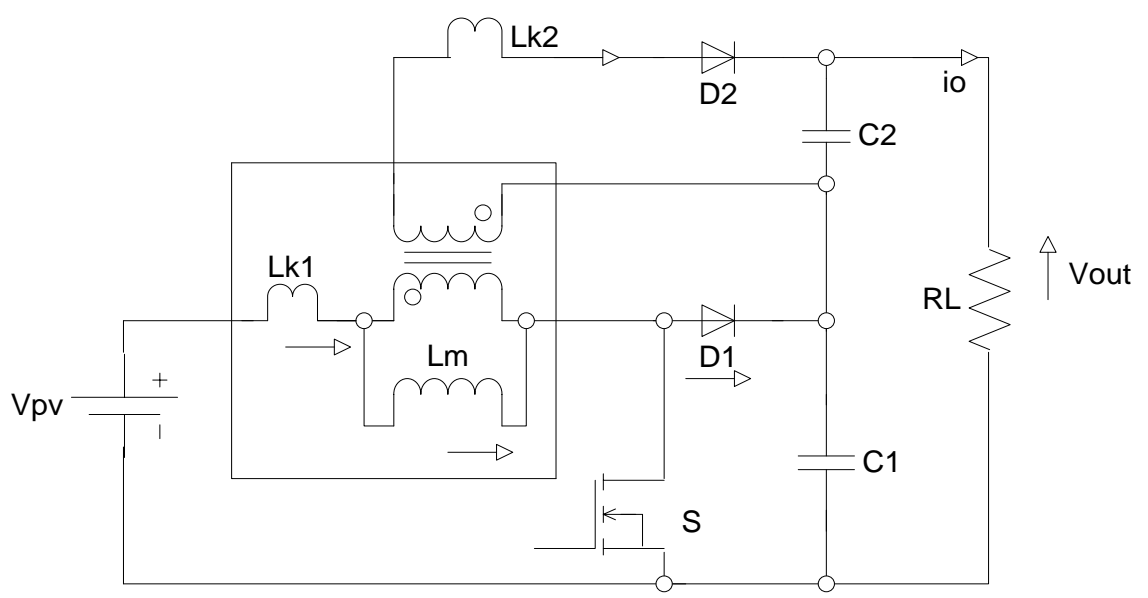

Figure 9. Novel high efficiency step up converter. 
implemented, simple control scheme, and compared to other topologies reviewed is still less in cost.

The advantages of the interleaved boost converter technique include low ripple amplitude and high frequency ripple power at the output and input waveforms due to an effective increase in switching frequency. So, there is a chance to minimalize the size of capacitors and inductors, whereas would be relatively large if conventional boost converter technology is used. Moreover, for alike power rating, the current flowing in each limb of the interleaved converter is lesser than a conventional boost converter, hence reducing overall $\left(\mathrm{i}^{2} \mathrm{r}\right)$ losses. Inappropriately, with low power conditions, interleaved boost converter operates in discontinuous current mode due to the current-split in the separated limbs. The consequences is obvious in photovoltaic applications once the interleaved boost converter is operated with low power level, will show low efficiency due the switching losses domination. In this case the presented conventional boost converter which has one branch to the current with fewer switches offers better efficiency.

For this reason, this paper proposed an interleaved boost converter with a new simple switch adaptive control scheme which is planned as shown in Figure 10. The aim is to increase the interleaved boost converter efficiency under low power level. The principle of the operation is to operate normally as an interleaved boost converter following the switch adaptive control procedures command. If there is a low irradiation (low power), one limb of the interleaved boost converter will bed is connected and all the available current will move in one phase of the interleaved boost converter (one switch, one diode, and one inductor). Ultimately, the interleaved boost converter will operating as normal in high power levels, and with lower power levels (low current), the interleaved boost converter will be controlled by novel switch adaptive control to operate as conventional boost converter.

The structure of the novel adaptive switch control is shown in Figure 11, has add good features to support the interleaved boost converter to function with high efficiency in location where the irradiance is changeable during the day. In addition, the proposed control is a simple in implementation with no extra cost [8].

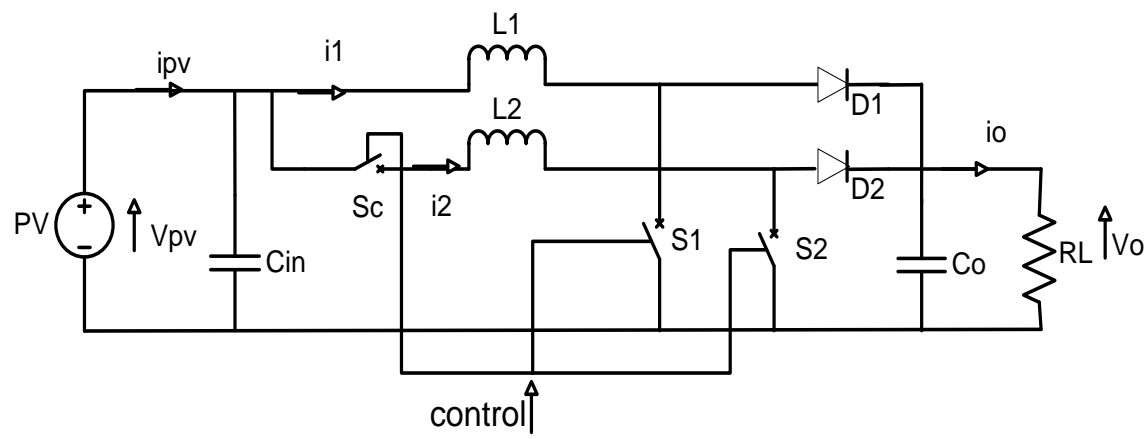

Figure 10. Interleaved boost converter with novel switch adaptive control. 


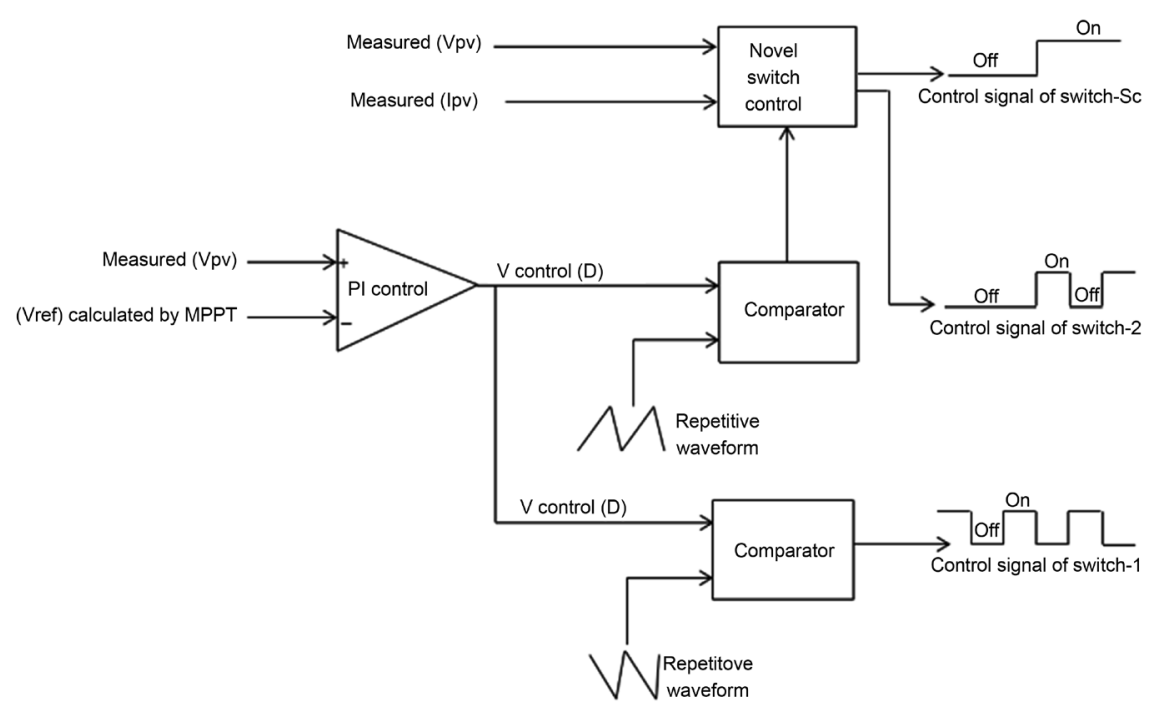

Figure 11. Control strategy of interleaved boost converter with novel switch adaptive control.

The major concern in the design of power boost converter is the number of components required, that will effect on size, cost of implementation, and efficiency. This paper has presented a comparison to nine different discussed boost converters as shown in Table 1, in relation to their cost of implementation and efficiency performance, taking to consideration the cost of sensors and microcontroller complexity. The table indicates that interleaved boost converter with novel switch adaptive control is in general the most efficient and relative cost is moderate compared to all analysed boost converters.

\section{Simulation Results}

To validate the theoretical analysis of the paper, stand-alone PV system is used with the selected (low-priced) boost converters. First, the perturbation and observation ( $\mathrm{P} \& \mathrm{O}$ ) method of maximum power point tracking (MPPT) control is used to secure maximum power generated from the solar panel. Further, to confirm the results, similar components are used in design of the chosen step-up converters as shown in Table 2. The system is modelled by Matlab/Semi-Power system to assess the selected boost converters in the stand-alone PV system as shown in Figure 12. Investigations are done with changeable solar power level using PV panel (HIP-210NH1-BO-1) in Table 3, by varying the irradiation conditions.

The designed adaptive switch control in Figure 11, measures the voltage and current of solar panel to monitor the power and follows a simple techniques of computation to operate the boost converter as conventional boost converter (connected-switch OFF) at low solar power when the power level is less than $80 \mathrm{~W}$, and as an interleaved boost converter (connected-switch ON) at high solar power when the power level is above $80 \mathrm{~W}$.

The selected DC-DC boost converters are tested with load $200 \mathrm{Ohm}$ and a PV 
panel of rated maximum 210W under increase in irradiation as shown in Figure 13(a) and Figure 13(b). In Figure 13(c), the conventional boost converter shows a decrease in efficiency when the photovoltaic power reaches almost 80 Watts, while the interleaved boost converter starts showing an improvement to efficiency when the power of the system rise. Figure 13(d), indicates that the

Table 1. Comparison to discussed boost converters.

\begin{tabular}{|c|c|c|c|c|c|c|c|c|c|c|}
\hline & 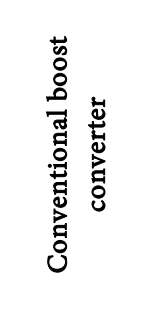 & 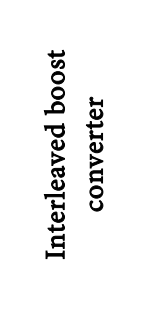 & 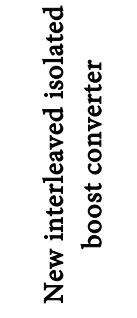 & 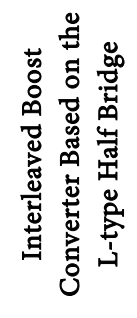 & 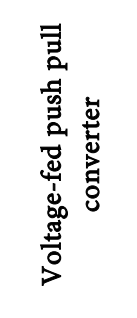 & 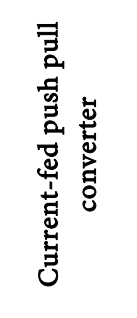 & 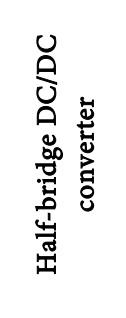 & 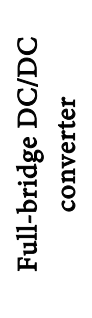 & 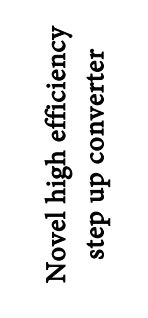 & 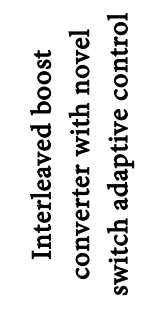 \\
\hline $\begin{array}{l}\text { Number of } \\
\text { Components } \\
\text { required } \\
\text { (effect on Size) }\end{array}$ & 5 & 8 & 16 & 16 & 8 & 8 & 9 & 9 & 9 & 9 \\
\hline $\begin{array}{l}\text { Expected Cost of } \\
\text { implementation }\end{array}$ & Very low & Low & Very high & Very high & Moderate & Moderate & Moderate & High & High & Moderate \\
\hline & $\begin{array}{c}\text { Low } \\
\text { efficiency } \\
\text { with high } \\
\text { power level }\end{array}$ & $\begin{array}{c}\text { High } \\
\text { efficiency } \\
\text { with high } \\
\text { power level }\end{array}$ & & & & & & & $\begin{array}{c}\text { High } \\
\text { efficiency } \\
\text { with high } \\
\text { power level }\end{array}$ & $\begin{array}{c}\text { High } \\
\text { efficiency } \\
\text { with high } \\
\text { power level }\end{array}$ \\
\hline Efficiency & & & low & Low & Moderate & Moderate & Low & Low & & \\
\hline & $\begin{array}{c}\text { and } \\
\text { High } \\
\text { efficiency } \\
\text { with low } \\
\text { power level }\end{array}$ & $\begin{array}{c}\text { and } \\
\text { Low } \\
\text { efficiency } \\
\text { with low } \\
\text { power level }\end{array}$ & & & & & & & $\begin{array}{c}\text { and } \\
\text { Low } \\
\text { efficiency } \\
\text { with low } \\
\text { power level }\end{array}$ & $\begin{array}{c}\text { and } \\
\text { High } \\
\text { efficiency } \\
\text { with low } \\
\text { power level }\end{array}$ \\
\hline
\end{tabular}

Table 2. Parameters of conventional boost converter circuit, interleaved boost converter circuit, and interleaved boost converter with novel switch adaptive control circuit.

\begin{tabular}{ccc}
\hline Parameters & $\begin{array}{c}\text { Circuit of Conventional } \\
\text { boost converter }\end{array}$ & $\begin{array}{c}\text { Circuits of Interleaved boost converter, } \\
\text { and Interleaved boost with novel } \\
\text { switch adaptive control }\end{array}$ \\
\hline Input capacitor & $9.5 \mu \mathrm{F}$ & $9.5 \mu \mathrm{F}$ \\
Inductor & $\mathrm{L} 1=1 \mathrm{mH}$ & $\mathrm{L} 1=1 \mathrm{mH}, \mathrm{L} 2=1 \mathrm{mH}$ \\
Frequency & $20,000 \mathrm{~Hz}$ & $20,000 \mathrm{~Hz}$ \\
Output Capacitor & $45 \mu \mathrm{F}$ & $45 \mu \mathrm{F}$ \\
Applied Load & $(200 \Omega)$ & $(200 \Omega)$ \\
Mosfet switch & $\mathrm{IPP} 075 \mathrm{~N} 15 \mathrm{~N} 3 \mathrm{G}$ & Two: IPP075N15N3 G \\
Diode & $\mathrm{BYW} 29 \mathrm{EX}-200$ & Two: BYW29EX-200 \\
Switch-connection $(\mathrm{Sc})$ & $/$ & (IRFB3077PBF)
\end{tabular}




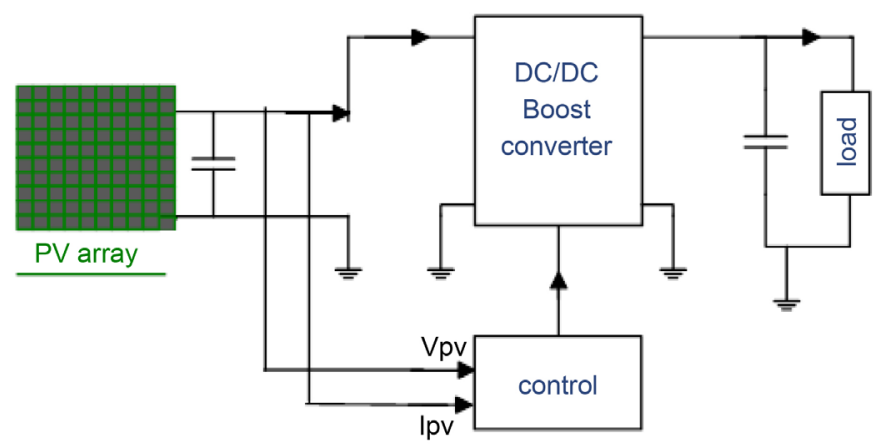

Figure 12. Schematic of used stand-alone photovoltaic system.

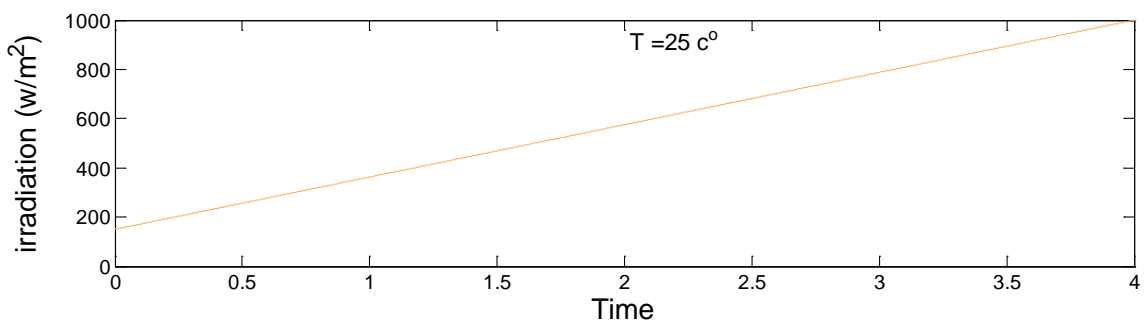

(a)

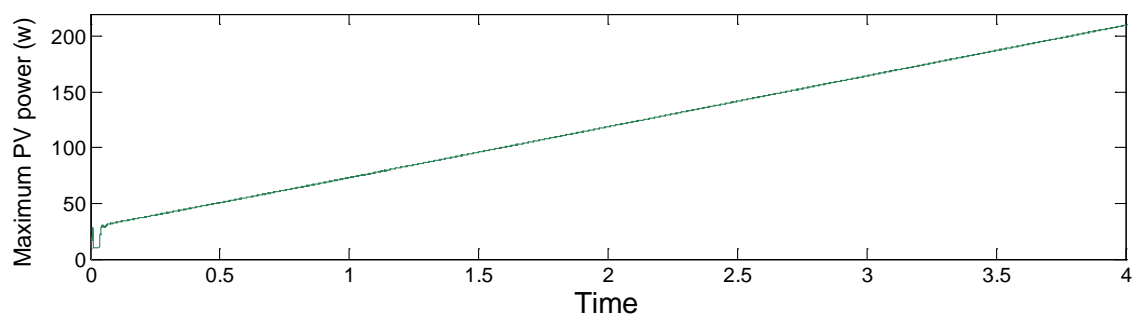

(b)

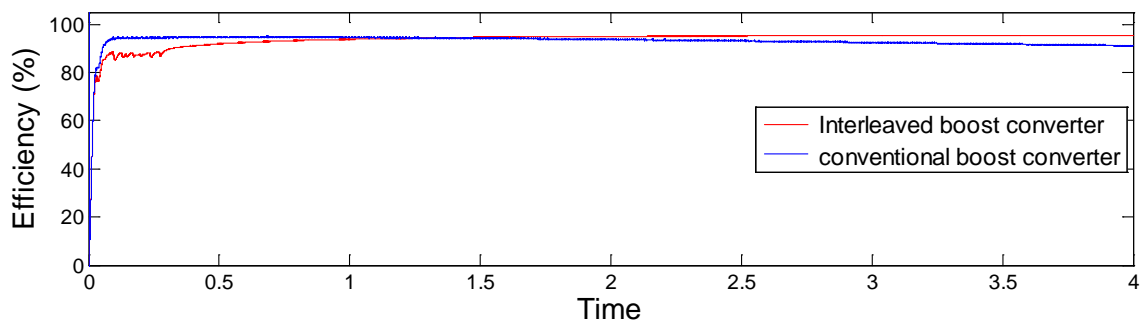

(c)

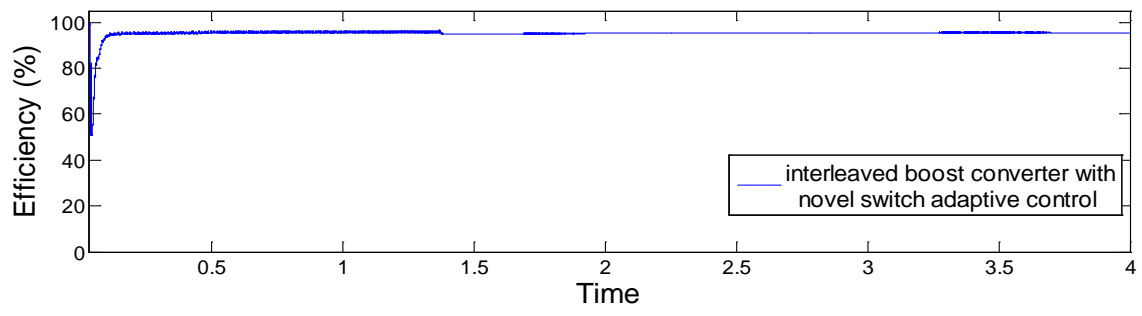

(d)

Figure 13. (a) Irradiation in increase with temperature $\left(25^{\circ} \mathrm{C}\right.$ ); (b) PV panel (HIP210NH1-BO-1) power under a rise irradiation; (c) Efficiency of conventional boost converter and interleaved boost converter; (d) Efficiency of interleaved boost converter with novel switch adaptive control. 
Table 3. The key data of the hip-210nh1-bo-1 photovoltaic module.

\begin{tabular}{cc}
\hline $\begin{array}{c}\text { Photovoltaic Module: } \\
\text { HIP-210NH1-BO-1 }\end{array}$ & $\begin{array}{c}\text { Irradiation }=1000 \mathbf{w} / \mathrm{m}^{2}, \\
\text { Temperature }=\mathbf{2 5 ^ { \circ } \mathrm { C }}\end{array}$ \\
\hline Maximum power (Pmax) & 210 (Watt) \\
Short circuit current (Isc) & 5.57 (Amp) \\
Open circuit voltage (Voc) & 50.9 (Volt) \\
Max. power current (Ipm) & 5.09 (Amp) \\
Max. power voltage (Vpm) & 41.3 (Volt) \\
\hline
\end{tabular}

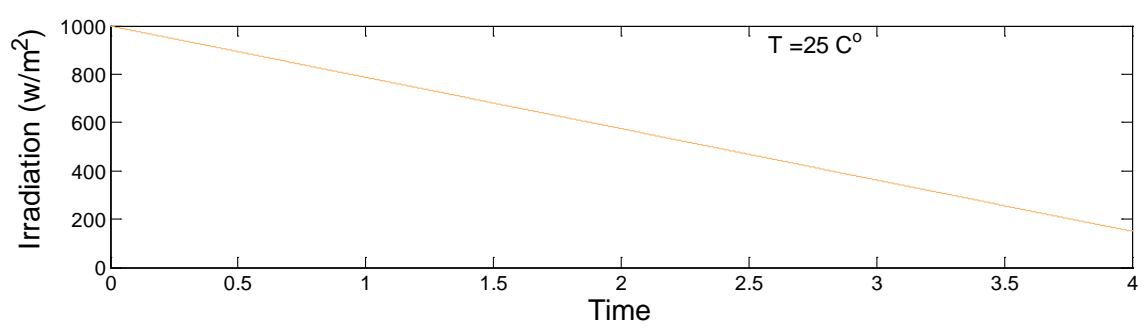

(a)

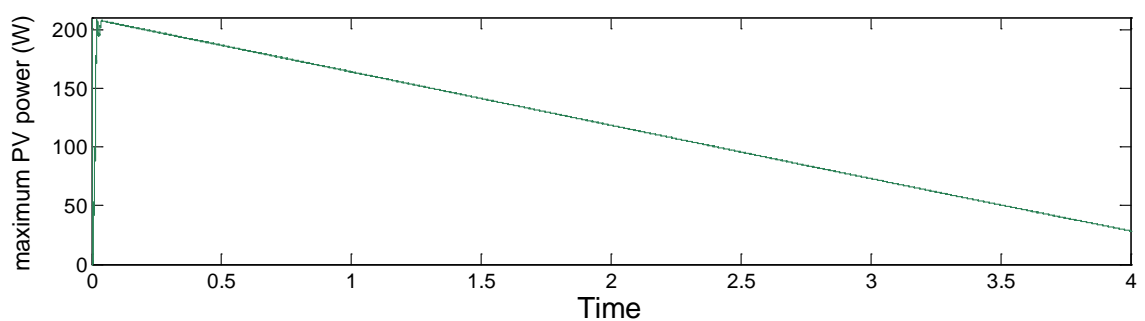

(b)

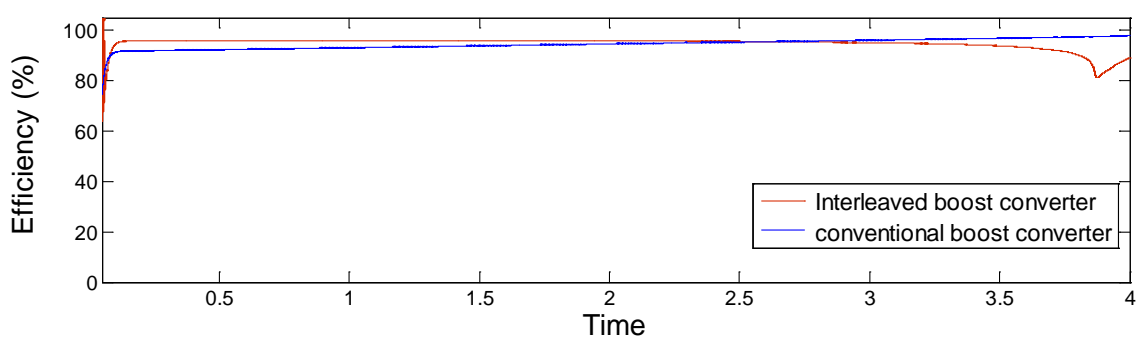

(c)

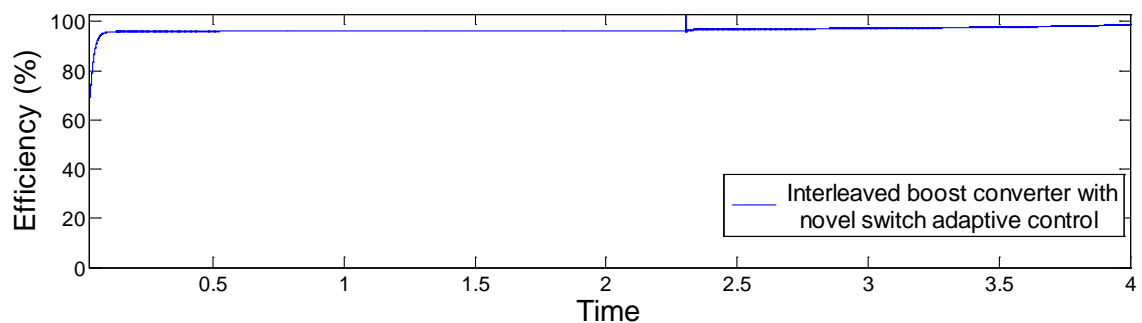

(d)

Figure 14. (a) Irradiation with reduction and temperature $\left(25^{\circ} \mathrm{C}\right)$; (b) PV panel (HIP-210NH1-BO-1) power under falling irradiation; (c) Efficiency of conventional boost converter and interleaved boost converter; (d) Efficiency of interleaved boost converter with novel switch adaptive control. 
circuit of interleaved boost converter with novel switch adaptive control shows a constant efficiency level of around $96 \%$ all the time.

Equally, then the preferred boost converters are tested under a fall in irradiation using the same solar panel of rate maximum 210 Watts with load $200 \mathrm{Ohm}$ as shown in Figure 14(a) and Figure 14(b). As seen in Figure 14(c), the conventional boost converter shows high efficiency when the power reaches approximately $80 \mathrm{~W}$, the efficiency starts dropping down, whereas the interleaved boost converter starts with lower efficiency level but at $80 \mathrm{~W}$ power level, then the efficiency starts increasing. Figure 14(d), exhibits that the interleaved boost converter with novel switch adaptive control displays a great steady efficiency of about $96 \%$ under a decrease in maximum PV power.

The results of simulation also reveal that the structure of interleaved boost converter with novel switch adaptive control exhibits a low ripple current and a low ripple voltage at the output and input stages, and a low stress on components. In addition, proposed circuit shows capabilities to operate in continuous current mode with varied weather conditions.

\section{Conclusion}

The paper presents an overview of boost converters, and considers their efficiency in photovoltaic applications that operate under a wide range of changeable weather conditions. From this, it is clear that each boost converter circuit has its own disadvantages and advantages, and the choice is decidedly application dependent. When using PV systems in destitute residential locations, the objective is to have low cost of PV systems that offer high efficiency under all operation conditions. To do so, it is necessary to combine the advantages of interleaved boost converter circuit and conventional boost converter circuit. Importantly, the proposed topology with its control scheme extends the range whereby the circuit operates in continuous conduction mode with very low irradiance conditions. The simulation results have confirmed that the circuit of interleaved boost converter with novel switch adaptive control has good features of low ripple of the current and voltage at the output and input stages, low stress on devices. It promises to operate in continuous current mode over a wider range of operating conditions, and offers optimised high efficiency under all weather conditions. In general, the circuit is a good choice for all PV systems that requires high efficiency operation in unpredictable weather conditions.

\section{References}

[1] Saravanan, S. and Ramesh Babu, N. (2017) A Modified High Step-Up Non-Isolated DC-DC Converter for PV Application. Journal of Applied Research and Technology, 15, 242-249. https://doi.org/10.1016/j.jart.2016.12.008

[2] Graditi, G., et al. (2010) Efficiency and Reliability Comparison of DC-DC Converters for Single Phase Grid Connected Photovoltaic Inverters. SPEEDAM 2010, 14th IEEE International Symposium Power Electronics, Electrical Drives, Automation and Motion, Pisa, 14-16 June 2010, 140-147. 
https://doi.org/10.1109/SPEEDAM.2010.5542235

[3] Martinot, E. and Sawin, J.L. (2012) Renewables 2012 Global Status Report. Renewable Energy Policy Network for the 21 st Century REN21.

[4] Yang, C.-Y., Hsieh, C.-Y., Feng, F.-K. and Chen, K.-H. (2012) Highly Efficient Analog Maximum Power Point Tracking (AMPPT) in a Photovoltaic System. IEEE Transactions on Circuits and Systems I: Regular Papers, 59, 1546-1556.

[5] Faranda, R. and Leva, S. (2008) Energy Comparison of MPPT Techniques for PV Systems. Wseas Transactions on Power Systems, 3, 447-455.

[6] Femia, N., Lisi, G., Petrone, G., Spagnuolo, G. and Vitelli, G. (2008) Distributed Maximum Power Point Tracking of Photovoltaic Arrays: Novel Approach and System Analysis. Transactions IEEE on Industrial Electronics, 55, 2610-2621. https://doi.org/10.1109/TIE.2008.924035

[7] Ali, A., Saied, M., Mostafa, M. and Abdel-Moneim, T. (2012) A Survey of Maximum PPT Techniques of PV Systems. Energytechnologies IEEE, Cleveland, 29-31 May 2012, 1-17. https://doi.org/10.1109/EnergyTech.2012.6304652

[8] Babaa, S. (2017) Novel Switch Adaptive Control to Improve the Efficiency of Boost Converter in Photovoltaic Systems. Journal of Power and Energy Engineering, 5, 1-14. https://doi.org/10.4236/jpee.2017.57001

[9] Lee, P.-W., Lee, Y.-S., Cheng, D.K.W. and Liu, X.-C. (2000) Steady-State Analysis of an Interleaved Boost Converter with Coupled Inductors. IEEE Transactions on Industrial Electronics, 47, 787-795. https://doi.org/10.1109/41.857959

[10] Veerachary, M., Senjyu, T. and Uezato, K. (2003) Neural-Network-Based Maximum-Power-Point Tracking of Coupled-Inductor Interleaved-Boost-ConverterSupplied PV System Using Fuzzy Controller. IEEE Transactions on Industrial Electronics, 50, 749-758. https://doi.org/10.1109/TIE.2003.814762

[11] Veerachary, M., Senjyu, T. and Uezato, K. (2003) Maximum Power Point Tracking of Coupled Inductor Interleaved Boost Converter Supplied PV System. Electric Power Applications, IEE Proceedings, 150, 71-80. https://doi.org/10.1049/ip-epa:20020686

[12] Berasategi, A., Cabal, C., Alonso, C. and Estibals, B. (2009) European Efficiency Improvement in Photovoltaic Applications by Means of Parallel Connection of Power Converters. 13th European Conference on Power Electronics and Applications, EPE, 9, 1-10.

[13] Bidoggia, B., Spiazzi, G., Buso, S., Lequeu, T. and Ventura, L. (2008) Design of a Fuel Cell Based Backup System for Telecoms Applications. Telecommunications Energy Conference, INTELEC 2008. IEEE 30 th International, San Diego, 31 October 2008, 1-8. https://doi.org/10.1109/INTLEC.2008.4664030

[14] Perreault, D.J. and Kassakian, J.G. (1997) Distributed Interleaving of Paralleled Power Converters. IEEE Transactions on Circuits and Systems I: Fundamental Theory and Applications, 44, 728-734. https://doi.org/10.1109/81.611269

[15] Lai, C.-M., Pan, C.-T. and Cheng, M.-C. (2012) High-Efficiency Modular High Step-Up Interleaved Boost Converter for DC-Microgrid Applications. IEEE Transactions on Industry Applications, 48, 161-171. https://doi.org/10.1109/TIA.2011.2175473

[16] Jun, W., Jin, T. and Smedley, K. (2006) A New Interleaved Isolated Boost Converter for High Power Applications. Applied Power Electronics Conference and Exposition, Dallas, 19-23 March 2006, 6.

[17] Cha, H., Choi, J. and Han, B. (2008) A New Three-Phase Interleaved Isolated Boost 
Converter with Active Clamp for Fuel Cells. Power Electronics Specialists Conference, Rhodes, 15-19 June 2008, 1271-1276.

[18] Wang, Y. and Klumpner, C. (2005) Optimal Design of a DC/DC Converter for Photovoltaic Applications. 31 st Annual Conference on Industrial Electronics Society, Raleigh, 6-10 November 2005, 6. https://doi.org/10.1109/IECON.2005.1569303

[19] Wang, J., Li, J. and Zhang, W. (2009) Interleaved Push-Pull Converter with Very Low Input and High Output. 2nd International Conference on Power Electronics and Intelligent Transportation System, Shenzhen, 19-20 December 2009, 247-249.

[20] Liang, T., Chen, R., Chen, J. and Tzeng, W.-J. (2007) Buck-Type Current-Fed Push-Pull Converter with ZCS for High Voltage Applications. Region 10 Conference TENCON, Taipei, 30 October-2 November 2007, 1-4.

[21] Vinnikov, D., Jalakas, T. and Egorov, M. (2008) Feasibility Study of Half- and Full-Bridge Isolated DC/DC Converters in High-Voltage High-Power Applications. 13 th Power Electronics and Motion Control Conference, Poznan, 1-3 September 2008, 1257-1262. https://doi.org/10.1109/EPEPEMC.2008.4635441

[22] Liu, C., et al. (2011) High-Efficiency Hybrid Full-Bridge-Half-Bridge Converter with Shared ZVS Lagging Leg and Dual Outputs in Series. IEEE Transactions on Power Electronics, 28, 849-861. https://doi.org/10.1109/TPEL.2012.2205019

[23] Tseng, K.C. and Liang, T.J. (2004) Novel High-Efficiency Step-Up Converter. Electric Power Applications, 151, 182-190. https://doi.org/10.1049/ip-epa:20040022

[24] Changchien, S.-K., Liang, T.-J., Chen, J.-F. and Yang, L.-S. (2010) Novel High Step-Up DC-DC Converter for Fuel Cell Energy Conversion System. IEEE Transactions on Industrial Electronics, 57, 2007-2017.

https://doi.org/10.1109/TIE.2009.2026364 